\author{
폐계가슴살 회수단백질을 활용한 돈육소시지의 품질 특성에 영향하는 동충하초, \\ 누에고치 및 Conjugated Linoleic Acid (CLA) 첨가 효과 \\ 진상근 ${ }^{1} \cdot$ 김일석 $^{1} \cdot$ 강석남 $^{1} \cdot$ 최승연 ${ }^{1} \cdot$ 허인철 $^{1} \cdot$ 이중근 $^{1} \cdot$ 양한술 $^{2}{ }^{*}$ \\ ${ }^{1}$ 진주산업대학교 동물소재공학과, ${ }^{2}$ 경상대학교 축산학과·경상대학교 농업생명과학연구원
}

\title{
Effect of Cordyceps ochraceostromat, Silkworm Cocoon, and Conjugated Linoleic Acid (CLA) on the Quality Characteristics of Pork Sausage Manufactured with Protein Recovered from Breast of Spent Laying Hen
}

Sang-Keun Jin ${ }^{1}$, Il-Suk Kim ${ }^{1}$, Suk-Nam Kang ${ }^{1}$, Seung-Yun Choi ${ }^{1}$, In-Chul Hur ${ }^{1}$, Jung-Guen Lee ${ }^{1}$ and Han-Sul Yang ${ }^{2 *}$

${ }^{1}$ Department of Animal Resources Technology, Jinju National University,

${ }^{2}$ Department of Animal Science, Gyeongsang National University · Institute of Agriculture and Life Science,

Gyeongsang National University

\begin{abstract}
This study was conducted to investigate the effects of Cordyceps ochraceostromat, silkworm cocoon, and conjugated linoleic acid (CLA) on the quality and storage properties of pork sausage manufactured with protein recovered from breast of spent laying hen during 4 wks of storage at $4^{\circ} \mathrm{C}$. Pork sausages were prepared using $100 \%$ ham (control) and $40 \%$ recovered protein from breast of spent laying hen to replace pork(T1), and with added different sources to final concentrations of $0.1 \%$ Cordyceps ochraceostromat powder (T2), $0.1 \%$ silkworm cocoon powder (T3), $0.1 \%$ CLA (T4), $0.05 \%$ Cordyceps ochraceostromat $+0.05 \%$ silkworm cocoon (T5), $0.05 \%$ Cordyceps ochraceostromat $+0.05 \%$ CLA (T6), and $0.05 \%$ silkworm cocoon $+0.05 \%$ CLA (T7). The treatments T5 and T7 had higher $(\mathrm{p}<0.05)$ protein content than control, but control had lower fat content than other samples during $4 \mathrm{wks}$ of storage at $4^{\circ} \mathrm{C}$. Lightness was significantly lower in the treatment samples than control. However, there was no significant difference in water holding capacity between the sausage samples, whereas, cohesiveness and chewiness were significantly higher $(p<0.05)$ in the control than other treatments. All sausage samples showed a significant increase in volatile basic nitrogen $(\mathrm{VBN})$ and total plate counts with extending storage time $(\mathrm{p}<0.05)$, and VBN values of treatments were lower than the control. However, the treatment samples showed a significant decrease $(p<0.05)$ in thiobarbituric acid reactive substances over the increasing storage time. Therefore, our results suggested that the $40 \%$ recovered protein to replace pork and with added different sources decreased lipid oxidation and protein denaturation of pork sausages, thereby enhancing self-life, compared to normal pork sausage (control).
\end{abstract}

(Key words : Spent laying hen, Recovered protein, Functional ingredients, Quality characteristics)

서 론

일반적으로 기능성 물질이란, 생체조절기능이나 방어능력을 가짐 으로써 건강을 유지하는데 주요한 역할을 할 뿐 아니라 식품에 첨 가 시 식품자체에 기능이 보유될 수 있어야 한다(Sadaki, 1996). 기능성이 입증된 물질 중 현재 식품 또는 의약 분야에서 널리 사용 되고 있는 conjugated linoleic acid(CLA)는 인체 내 생리 기능 조절 및 항상성 유지 등에 긍정적으로 작용한다(Terpstra, 2004; Wang과 Jones, 2004). 그리고 동충하초와 누에고치에서는 면역기
능 증강 및 항암효과(Hung 등, 2007; Rao 등, 2007) 뿐만 아니 라, 혈중 콜레스테롤 저하(Sugiyama 등, 1985)와 당뇨병 치료 (Nam과 Oh, 1995) 등의 효과가 입증되었다.

수리미는 어육을 마쇄하여 수세 공정을 통해 근장단백질, 지질, 비단백태 질소 화합물 등을 제거하고 근원섬유단백질만을 농축한 후 냉동 변성 방지제를 혼합한 염용성 어육단백질로서 다양한 수산 식품을 가공하기 위한 중간 소재로 사용되며(Park과 Morrissey, 2000) 전세계적으로 게맛살이나 어묵의 형태로 가공-이용되고 있 다(Kristinsson과 HuHultin, 2003). 이러한 수리미의 가공 기술은

* Corresponding author: Han-Sul Yang, Department of Animal Science, Gyeongsang National University, 900 Gajwa-dong, Jinju, Gyeongnam 660-701. Tel: 82-55-751-5515, Fax: 82-55-756-7171, E-mail: hsyang@gnu.kr 
처리비용뿐만 아니라 산업적 활용도가 떨어지는 노폐계육 및 발골 후 뼈에 부착되어 있는 고기들을 기계로 회수한 여러 고기들 mechanically recovered meat(MRM), mechanically deboned chicken meat(MDCM)을 활용하여 축육으로부터 육단백질을 회수 하는데 그 원리를 적용(Knight, 1992)한 이후 상대적으로 살코기 부위가 많은 닭가슴살, 돈육 뒷다리 및 축산부산물인 심장 등을 활 용하여 소비촉진 및 새로운 제품 개발에 이용되고 있다.

이렇듯 선호도가 낮은 비선호 축산물을 이용한 회수단백질의 새 로운 활용방안과 더불어 회수물 자체의 조직학 및 관능적 특성 등 을 고려한 회수단백질을 첨가 또는 대체하여 새로운 조직을 재현할 수 있는 대체 수준에 관한 연구가 다양하게 이루어져 왔다. 예를 들어, Totosaus (2004)는 소와 돼지 심장 근육으로부터 추출한 수 리미 유사물의 첨가 및 대체를 통하여 프랑크푸르트소시지의 조직 특성을 변화시킬 수 있었다고 보고한 바 있다. 그리고 Jin 등 (2008a)은 어육 소시지의 제조시 닭가슴살 수리미를 활용하여 명 태연육의 $35 \%$ 까지 대체가 가능하며 노폐계육 수리미를 활용한 축 육 소지지 제품의 경우 회수단백질의 $40 \%$ 대체수준은 기존 제품 과 큰 차이가 없었다고 보고하였다(Jin 등, 2007b). 그러나 회수된 어육 및 축육단백질은 제품제조 전 기능적 변화를 최소화하기 위해 필수적으로 냉동시키는데 이러한 냉동과정은 근원섬유단백질을 변 성시켜 기능적 특성인 보수력을 감소시키는 것이 문제점으로 지적 되어 왔다(Richards 등, 1998).

따라서 본 연구는 일반 축육제품 형태로의 시제품 제작에 앞서 노폐계육 회수단백질의 산업적 활용도를 높임과 동시에 적정 첨가 량 설정을 위하여 $40 \%$ 회수단백질을 축육제품에 활용할 수 있는 가능성을 동충하초, 누에고치 및 CLA 첨가를 통한 기능성 축산물 생산에 관한 기초 자료를 제시코자 본 연구를 실시하였다.

\section{재료 및 방법}

\section{1. 실험재료 및 수리미 제조}

근막과 과다 지방을 제거 정형한 돼지 뒷다리 부위인 햄육과 등 지방을 chopper (MGB-32, Fugee, Korea)를 이용하여 $5 \mathrm{~mm}$ 로 분 쇄하였다. 또한 $\mathrm{MDCM}$ 즉, 노폐계육 회수단백질은 (주)싱그린푸드 시스템사의 것을 이용하여 제조하였다. 이때 회수단백질은 수분 $74.2 \%$, 단백질: $23.5 \%$ 및 지방: $2.1 \%$ 였다. 정형이 끝난 회수단백 질은 원료육인 햄육과 동일하게 chopper로 $5 \mathrm{~mm}$ 크기로 분쇄한 후 silent cutter(AS-30, Ramon Co., Oiartzum, Spain)로 미세하 게 4분간 커팅 후 6 배 중량의 물을 가하여 homogenizer(T25B, IKA Sdn. Bhd., Malaysia)로 8,000 rpm에서 30초 간 균질하였 다. 균질액을 표준체 3.5 와 18 번으로 각각 여과한 후 여과액에 1 $\mathrm{N} \mathrm{NaOH}$ 로 종래의 수세법과 달리 단백질 추출을 위하여 $\mathrm{pH}$ 조절 법(Jung 등, 2004)에 따라 알칼리 조건인 $\mathrm{pH} 11.0$ 으로 조절하여 3상 연속원심분리기(J-1250, Hanil Science, Korea)로 $10,000 \times \mathrm{g}$ 에서 단백질을 추출하였다. 이 때 최상층(중성지방 등 유화층)과
최저층(결체조직, 막지질 등)을 버리고 중간층(염용성 및 수용성 단 백질)을 회수하였다. 회수된 시료는 $1 \mathrm{~N} \mathrm{HCl}$ 을 이용하여 $\mathrm{pH} 5.0$ 으로 조절하고 30 분간 방치한 후 $10,000 \times \mathrm{g}$ 에서 25 분간 원심분리 하여 하층의 회수물은 수분을 $80 \%$ 로 조절하였다.

\section{2. 소시지 제조}

소시지 제조를 위해 $100 \%$ 돈육만을 사용한 대조구와 노폐계육 회수단백질을 돈육에 대비 $40 \%$ 수준으로 대체한 $\mathrm{T} 1$, 회수단백질 을 $40 \%$ 대체한 배합비에 $0.1 \%$ 의 동충하초 분말을 첨가한 $\mathrm{T} 2$, $0.1 \%$ 누에고치 분말을 첨가한 $\mathrm{T} 3$ 및 $0.1 \% \mathrm{CLA}$ 첨가구를 $\mathrm{T} 4$ 로 동충하초, 누에고치 분말 및 $\mathrm{CLA}$ 를 각각 $0.05 \%$ 씩 첨가하여 $\mathrm{T} 5$, $\mathrm{T} 6$ 및 $\mathrm{T} 7$ 으로 설정하였다(Table 1). 이 때 사용된 동충하초(동충 하초환, 농진농원, 함양, 한국), 누에고치(누에환, 농진농원, 함양, 한국) 및 CLA(80 HGR, Nisshin Oillio Group Ltd, Japan)는 시 판-유통되고 있는 것을 구입하여 사용하였다. 첨가량을 동일하게 $0.1 \%$ 로 설정 한 것은 예비실험 결과, $0.1 \%$ 이상의 첨가수준에서 는 외관 등 여러 가지 면에 부적절한 영향을 미쳐 3 종류의 첨가 물을 동일한 함량으로 설정하였다.

모든 처리구들은 동일하게 silent cutter bowl에 깔고 1단으로 커팅하면서 염지제인 nitrite phosphate salt(NPS), 인산염, 설탕, monosodium glutamate(MSG)를 투입한 후 2단으로 올려 커팅하 였다. 이때 얼음은 2 번에 나누어 투입하고 이어서 $5^{\circ} \mathrm{C}$ 전후 시 지 방, 향신료 및 처리구별 기능성 물질 등을 투입하여 커팅하며 총소 요시간은 10 분, 유화물의 최종온도는 $14^{\circ} \mathrm{C}$ 이하에서 종료하였다. 한 쪽을 clipping한 fibrous 유색 $(2 \mathrm{G}, 15 \mathrm{~cm})$ 케이싱에 충진 후 steam chamber(SAA10, Steammaster, Germany)를 이용하여 중 심온도 $75^{\circ} \mathrm{C}$ 에 도달할 때까지 가열하였다. 가열이 끝난 샘플은 $4^{\circ} \mathrm{C}$ 냉장고에서 24 시간 냉각 후, 본 연구를 위한 공시 재료로 사 용하였으며, 냉각이 끝난 샘플을 저장 0 주차로 설정하여 4주 저장 하면서 돈육 소시지의 품질 및 저장 특성을 분석하였다.

\section{3. 분석 방법}

일반성분은 AOAC (1990) 방법, 수분은 건조법, 단백질 함량은 Micro kjeldahle 방법, 지방 함량은 Soxhlet 추출법 및 회분 함량 은 $550^{\circ} \mathrm{C}$ 직접회화법으로 각 시료당 3 회 반복 측정하였다. $\mathrm{pH}$ 는 근막, 지방 등을 제거한 후 세절한 시료 $10 \mathrm{~g}$ 을 증류수 $90 \mathrm{ml}$ 와 함 께 Homogenizer(T25B, IKA Sdn, Bhd., Malaysia)로 13,500 $\mathrm{rpm}$ 에서 10초간 균질하여 $\mathrm{pH}-\mathrm{meter}(8603$, Metrohm, Swiss)로 측정하였다. 표면 육색(CIE L*)은 chromameter(CR-400, Minolta(Co., Japan, $10^{\circ} \mathrm{C}$ standard observer and Model 45/0 $\mathrm{LAV}$ )를 사용하여 소시지 시료 단면적을 균일하게 9회 반복 측정 하였다. 이때, 표준색 판은 $\mathrm{L}^{*}=89.2, \mathrm{a}^{*}=0.921, \mathrm{~b}^{*}=0.783$ 의 조건 인 것을 사용하였다. 보수력(water holding capacity)은 원심분리 법을 이용하여 마쇄한 소시지 batter 시료 $10 \mathrm{~g}$ 을 $50 \mathrm{ml}$ 
Table 1. The basic formulation of sausage batter with ingredients

\begin{tabular}{|c|c|c|c|c|c|c|c|c|}
\hline \multirow{2}{*}{ Ingredients } & \multicolumn{8}{|c|}{ Treatments $^{1)}$} \\
\hline & $\mathrm{C}$ & $\mathrm{T} 1$ & $\mathrm{~T} 2$ & $\mathrm{~T} 3$ & $\mathrm{~T} 4$ & T5 & T6 & $\mathrm{T} 7$ \\
\hline Ham & 3,620 & 2,172 & 2,172 & 2,172 & 2,172 & 2,172 & 2,172 & 2,172 \\
\hline $\mathrm{pH}$ adjusted breast muscle of spend laying hens & - & 1,448 & 1,448 & 1,448 & 1,448 & 1,448 & 1,448 & 1,448 \\
\hline Back fat & 560 & 560 & 560 & 560 & 560 & 560 & 560 & 560 \\
\hline Ice & 690 & 690 & 690 & 690 & 690 & 690 & 690 & 690 \\
\hline NPS (nitrite phosphate salt) & 70 & 70 & 70 & 70 & 70 & 70 & 70 & 70 \\
\hline Phosphate & 10 & 10 & 10 & 10 & 10 & 10 & 10 & 10 \\
\hline Sugar & 25 & 25 & 25 & 25 & 25 & 25 & 25 & 25 \\
\hline MSG (monosodium glutamate) & 3 & 3 & 3 & 3 & 3 & 3 & 3 & 3 \\
\hline Mixed spices & 20 & 20 & 20 & 20 & 20 & 20 & 20 & 20 \\
\hline Cordyceps ochraceostromat powder & - & - & 5 & - & - & 2.5 & 2.5 & - \\
\hline Silkworm cocoon powder & - & - & - & 5 & - & 2.5 & - & 2.5 \\
\hline CLA & - & - & - & - & 5 & - & 2.5 & 2.5 \\
\hline Total & 4,975 & 4,975 & 4,980 & 4,980 & 4,980 & 4,980 & 4,980 & 4,980 \\
\hline
\end{tabular}

${ }^{1)}$ Control pork sausage, T1: 40\% of pork was replaced with $\mathrm{pH}$ adjusted breast muscle of spent laying hen (recovered protein), T2: $40 \%$ recovered protein from spend laying hen with $0.1 \%$ Cordyceps ochraceostromat powder, T3: $40 \%$ recovered protein from spend laying hen with $0.1 \%$ silkworm cocoon powder, T4: $40 \%$ recovered protein from spend laying hen with $0.1 \%$ CLA, T5: 40\% recovered protein from spend laying hen with $0.05 \%$ Cordyceps ochraceostromat $+0.05 \%$ silkworm cocoon powder, T6: $40 \%$ recovered protein from spend laying hen with $0.05 \%$ Cordyceps ochraceostromat $+0.05 \%$ CLA, and T7: $40 \%$ recovered protein from spend laying hen with $0.05 \%$ silkworm cocoon powder $+0.05 \%$ CLA.

polycarbonate tubes에 담근 후 $90^{\circ} \mathrm{C}$ 의 항온수조에서 15 분간 가열 한 다음 냉각하여 $3,000 \mathrm{rpm}$ 에서 20 분간 원심분리(Union $5 \mathrm{KR}$, Hanil, Korea) 한 후 무게를 측정하였다. $\mathrm{WHC}(\%)=(1-$ 가열 및 원심분리 후 수분 손실 양) $\times 100 /($ 샘플 내 총 수분 함량). 가열감량 (cooking loss)은 Boles와 Swan(1996)의 방법에 따라 시료를 가 열전 샘플 무게를 측정한 다음 $90^{\circ} \mathrm{C}$ 항온 수조에서 15 분간 가열후 15 분 동안 방냉시킨 후 가열 후 샘플 무게를 측정한 후 가열감량 $(\%)=($ 가열전 무게 - 가열후 무게 $) /$ 가열전 무게 $\times 100$ 의 식으로 계산 하였다. 조직감은 분석전 가열된 소시지를 상온에서 1 시간 방치 후 직경 $3 \mathrm{~cm}$, 높이 $2 \mathrm{~cm}$ 크기로 잘라 Instron Universal Testing Machine(Model 3343)을 이용하여, 1회 측정 시 70\% 침투력 및 2회 반복의 조건으로 경도(hardness), 응집성(cohesiveness), 탄력 성(springiness), 검성(gumminess) 및 씹힘성(chewiness) 등을 각 처리구마다 5 회 반복하여 측정하였다. 이때 분석기기 조건은 head speed: $100 \mathrm{~mm} / \mathrm{min}$, road cell: $50 \mathrm{~kg}$ 이었다. 지방산패도 값인 thiobarbituric acid reactive substances(TBARS)는 Buege와 Aust (1978)의 방법에 따라 시료 $5 \mathrm{~g}$ 에 butylated hydroxyanisole(BHA) $50 \mu 1$ 와 증류수 $15 \mathrm{ml}$ 를 첨가하여 균질화 시킨 후 균질액 $1 \mathrm{ml}$ 를 시험관에 넣고 여기에 $2 \mathrm{ml}$ thiobarbituric acid(TBA)/trichloroacetic acid(TCA) 혼합용액을 넣어 완전히 혼 합한 다음, $90^{\circ} \mathrm{C}$ 의 항온수조에서 15 분간 열처리한 후 냉각시켜 $3,000 \mathrm{rpm}$ 에서 10 분간 원심분리시켰다. 원심분리한 시료의 상층을 회수하여 $531 \mathrm{~nm}$ 에서 측정한 흡광도에 5.88 을 곱하여 $\mathrm{mg}$
$\mathrm{MA}($ malonaldehyde) $/ \mathrm{kg}$ 으로 나타내었다. 휘발성염기태질소화합물 즉, $\mathrm{VBN}$ (volatile basic nitrogen)은 高坂(1975)의 방법에 따라 세절육 $3 \mathrm{~g}$ 에 증류수 $27 \mathrm{ml}$ 를 가하여 $14,000 \mathrm{rpm}$ 에서 30 초간 균 질한 후 균질액을 여과지(Whatman No. 1)로 여과하였다. 여과된 균질액은 conway unit 접착부에 glycerin을 바르고 외실에 여과액 $1 \mathrm{ml}$ 를 넣고 내실에는 $0.01 \quad \mathrm{~N} \mathrm{H}_{3} \mathrm{BO}_{3} \quad 1 \mathrm{ml}$ 와 지시약 $(0.066 \%$

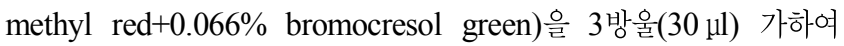
뚜껑을 닫은 후 $50 \% \mathrm{~K}_{2} \mathrm{CO}_{3} 1 \mathrm{ml}$ 를 외실에 신속히 주입하였다. 주입이 끝난 용기는 밀폐시킨 다음 용기를 수평으로 교반하여 여과 액과 $50 \% \mathrm{~K}_{2} \mathrm{CO}_{3}$ 을 잘 혼합시킨 후 $37^{\circ} \mathrm{C}$ 에서 120 분간 배양하였 다. 배양 후 $0.02 \mathrm{~N} \mathrm{H}_{2} \mathrm{SO}_{4}$ 로 내실의 붕산용액을 측정하여 $\mathrm{mg} \%$ 로 나타내었다.

$$
\begin{aligned}
& \mathrm{VBN}(\mathrm{mg} \%)=0.28 \times(\mathrm{a}-\mathrm{b}) \times \mathrm{F} \times 100 / 0.1 \\
& \mathrm{a}: \text { 본시험 적정치 }(\mathrm{ml}), \mathrm{b}: \text { 공시험 적정치 }(\mathrm{ml}) \text {, } \\
& \mathrm{F}: 0.02 \mathrm{~N} \mathrm{H}_{2} \mathrm{SO}_{4} \text { factor }
\end{aligned}
$$

돈육 소시지의 총균수는 시료 $10 \mathrm{~g}$ 을 $1 \%$ peptone 수 $90 \mathrm{ml}$ 에 넣고 Bagmixer(Interscience, German)로 균질시킨 다음 $1 \mathrm{ml}$ 를 채취하여 준비된 $9 \mathrm{ml}$ peptone수에 넣어 희석한 후, 희석액을 미 리 조제한 배지(plate count agar, Difco Laboratories, Sparks, $\mathrm{MD}, \mathrm{USA}$ )에 접종하고 $32^{\circ} \mathrm{C}$ 에서 2 일 배양한 후 나타나는 콜로니 수를 계수하였다.

관능요원들은 진주산업대학교의 학생 및 교직원으로 구성되었으 
며 요원선발, 훈련 및 검사 등은 Meigaard 등 (1999)의 방법에 따 라 실시하였다. 처음 2 주간 15 명의 요원을 선발 후 기존에 판매되 고 있는 소시지 제품에 관한 선행 평가에서 관능 요원으로서 연구 진행이 어렵다 판단되는 5 명을 추려 최종 10 명의 관능평가 요원을 선발하였다. 선발된 요원들은 $100 \%$ 햄육 소시지를 대조구로 하여 $40 \%$ 회수단백질 대체구뿐만 아니라 각각 $0.1 \%$ 기능성 물질 첨가 제품을 제조하여 2 주간 관능평가 요원들의 훈련을 진행하였다. 기 초 테스트인 짠맛과 단맛을 기초로 하여 향(aroma), 풍미(cooked sausage flavor and ingredients flavor) 및 조직감에 대한 평가를 관능평가 용지에 표시하게 하였다. 각각의 소시지 샘플들은 $(2.0 \times 2.0 \times 1.0 \mathrm{~cm})$ 각각 평가전 $35^{\circ} \mathrm{C}$ 로 재가열 후 뚜껑이 있는 유 리 컨테이너(Pyrex, Charleroi, PA) 에 담아 요원들에게 공급하여 9점 척도법으로 절단면의 색(1: 창백한 및 9: 어두운)과 제품의 향 (1: 약함 및 9: 강함) 또한 소시지를 씹었을 때 표현되는 풍미(1: 약함 및 9: 강함), 연도(1: 질김 및 9: 연함), 다즙성(1: 적음 및 9: 많음) 및 전체적인 기호도(1: 싫어함 및 9: 좋아함)로 표현하게 하 였다.

\section{4. 통계분석}

이상의 실험에서 얻어진 결과는 SAS Institute(1999)의 GLM(general linear model) 방법으로 분석하였으며, 처리 평균 간의 비교를 위해 Duncan의 multiple range test를 이용하였다.

\section{결과 및 고찰}

\section{1. 일반성분}

기능성 물질의 첨가에 따른 회수단백질을 활용한 돈육소시지의 저장 중 일반성분 변화는 Table 2와 같다. 저장 0 주차에 비해 저 장 4주차의 수분 함량 결과, $\mathrm{T} 1, \mathrm{~T} 3$ 및 $\mathrm{T} 6$ 에서 낮게 나타나 저장 기간이 증가할수록 수분 함량이 감소하였다. 또한 수분, 단백질 및 지방함량은 저장 초기인 0 주차엔 모든 처리구에서 유의적인 차이 가 없었으나, 저장 말기인 4주차엔 다른 처리구들에 비해 T4에서 낮은 수분 함량을 나타내었다 $(\mathrm{p}<0.05)$, 단백질 함량은 대조구에 비 해 $\mathrm{T} 5$ 와 $\mathrm{T} 7$ 에서 높은 함량을 나타내며 회수단백질 및 기능성 물 질 첨가시 대조구에 비해 전반적으로 높은 경향을 나타내었다. 지 방 함량의 경우, 대조구에 비해 $40 \%$ 회수단백질 처리구인 $\mathrm{T} 1$ 및 $\mathrm{T} 6$ 에서 높게 나타났다 $(\mathrm{p}<0.05)$. 그러나 다른 처리구들은 대조구와 차이가 없었다. 또한 회분 함량은 저장 0 주차엔 $\mathrm{T} 2$ 에서 낮게 나타

Table 2. Effect of functional ingredients on proximate composition (\%) of sausage manufactured by spent hens breast recovered protein during storage at $4^{\circ} \mathrm{C}$

\begin{tabular}{lcccccccc}
\hline \multirow{2}{*}{ Items } & \multicolumn{7}{c}{ Treatments $^{1)}$} \\
\cline { 2 - 9 } & $\mathrm{C}$ & $\mathrm{T} 1$ & $\mathrm{~T} 2$ & $\mathrm{~T} 3$ & $\mathrm{~T} 4$ & $\mathrm{~T} 5$ & $\mathrm{~T} 6$ & $\mathrm{~T}$ \\
\hline \hline \multicolumn{2}{l}{ Storage period $(0 \mathrm{wk})$} & & & & & & & \\
Moisture & $68.11 \pm 0.37$ & $68.71 \pm 0.51^{\mathrm{a}}$ & $68.54 \pm 0.57$ & $68.91 \pm 0.19^{\mathrm{a}}$ & $68.39 \pm 2.94$ & $67.83 \pm 0.71$ & $68.90 \pm 0.61^{\mathrm{a}}$ & $68.34 \pm 0.94$ \\
C. protein & $16.78 \pm 0.06$ & $16.86 \pm 0.25$ & $16.73 \pm 0.42$ & $16.59 \pm 0.53$ & $17.28 \pm 0.62$ & $16.97 \pm 0.74$ & $16.52 \pm 0.35$ & $17.08 \pm 0.35$ \\
C. fat & $12.61 \pm 2.14$ & $14.48 \pm 1.02$ & $12.43 \pm 1.06$ & $14.18 \pm 2.41$ & $13.18 \pm 3.21$ & $13.63 \pm 0.82^{\mathrm{a}}$ & $14.27 \pm 0.45$ & $12.84 \pm 0.37$ \\
C. ash & $2.19 \pm 0.04^{\mathrm{AB}}$ & $2.05 \pm 0.13^{\mathrm{B}}$ & $1.90 \pm 0.07^{\mathrm{Cb}}$ & $2.25 \pm 0.12^{\mathrm{A}}$ & $2.21 \pm 0.09^{\mathrm{A}}$ & $2.15 \pm 0.03^{\mathrm{AB}}$ & $2.16 \pm 0.04^{\mathrm{AB}}$ & $2.25 \pm 0.07^{\mathrm{A}^{*}}$ \\
\hline
\end{tabular}

Storage period (4 wks)

\begin{tabular}{lcccccccc} 
Moisture & $67.94 \pm 0.60^{\mathrm{A}}$ & $66.53 \pm 0.64^{\mathrm{Ab}}$ & $67.73 \pm 0.77^{\mathrm{A}}$ & $66.88 \pm 0.87^{\mathrm{Ab}}$ & $64.64 \pm 0.89^{\mathrm{B}}$ & $66.59 \pm 0.87^{\mathrm{A}}$ & $67.35 \pm 0.58^{\mathrm{Ab}}$ & $66.86 \pm 0.93^{\mathrm{A}}$ \\
C. protein & $16.57 \pm 0.38^{\mathrm{C}}$ & $16.65 \pm 0.39^{\mathrm{BC}}$ & $17.34 \pm 0.44^{\mathrm{ABC}}$ & $17.22 \pm 0.58^{\mathrm{ABC}}$ & $16.72 \pm 0.34^{\mathrm{BC}}$ & $17.70 \pm 0.25^{\mathrm{A}}$ & $17.24 \pm 0.56^{\mathrm{ABC}}$ & $17.44 \pm 0.18^{\mathrm{AB}}$ \\
C. fat & $11.87 \pm 0.18^{\mathrm{CD}}$ & $12.91 \pm 0.75^{\mathrm{AB}}$ & $11.45 \pm 0.82^{\mathrm{D}}$ & $12.04 \pm 0.47^{\mathrm{BCD}}$ & $11.59 \pm 0.09^{\mathrm{D}}$ & $11.89 \pm 0.66^{\mathrm{CDb}}$ & $13.41 \pm 0.54^{\mathrm{A}}$ & $12.72 \pm 0.37^{\mathrm{ABC}}$ \\
C. ash & $2.29 \pm 0.07^{\mathrm{A}}$ & $2.05 \pm 0.10^{\mathrm{B}}$ & $2.07 \pm 0.07^{\mathrm{Ba}}$ & $2.11 \pm 0.11^{\mathrm{B}}$ & $2.17 \pm 0.03^{\mathrm{B}}$ & $2.11 \pm 0.04^{\mathrm{B}}$ & $2.13 \pm 0.02^{\mathrm{B}}$ & $2.08 \pm 0.01^{\mathrm{B}}$ \\
\hline
\end{tabular}

${ }^{1)}$ Control pork sausage, T1: $40 \%$ of pork was replaced with pH adjusted breast muscle of spent laying hen (recovered protein), T2: $40 \%$ recovered protein from spend laying hen with $0.1 \%$ Cordyceps ochraceostromat powder, T3: 40\% recovered protein from spend laying hen with $0.1 \%$ silkworm cocoon powder, T4: 40\% recovered protein from spend laying hen with $0.1 \%$ CLA, T5: 40\% recovered protein from spend laying hen with $0.05 \%$ Cordyceps ochraceostromat $+0.05 \%$ silkworm cocoon powder, T6: $40 \%$ recovered protein from spend laying hen with $0.05 \%$ Cordyceps ochraceostromat $+0.05 \%$ CLA, and T7: 40\% recovered protein from spend laying hen with $0.05 \%$ silkworm cocoon powder $+0.05 \%$ CLA. $n=3$.

${ }^{\text {A-D }}$ Means with different superscript capital letters in a row are significantly different $(\mathrm{p}<0.05)$.

${ }^{\mathrm{a}-\mathrm{b}}$ Means with different superscript small letters in a column are significantly different $(\mathrm{p}<0.05)$. 
났으며 저장 4 주차에선 대조구에 비해 모든 처리구에서 낮게 나타 났다 $(\mathrm{p}<0.05)$.

\section{2. 물리적 특성}

물리적 특성인 $\mathrm{pH}$, 보수력, 가열감량 및 육색 변화는 Table 3과 같다. $\mathrm{pH}$ 의 경우, 모든 처리구에서 저장 4주차에 유의적으로 증가 하였으며, 저장 0 주차와 4 주차 모두 대조구에 비해 처리구에서 높 게 나타났다 $(\mathrm{p}<0.05)$. 특히 대조구에 비해 $\mathrm{T} 1$ 에서 월등히 높은 $\mathrm{pH}$ 값을 보여 회수단백질의 첨가를 통한 제품내 $\mathrm{pH}$ 상승을 가져 온 것으로 판단된다. 보수력 측정 결과, 처리구들간 비교시 0 일차 엔 T1에서 가장 높은 보수력을 보였으며, T6 및 T7에서 T1에 비 해 낮은 값을 나타내었다. 또한 $100 \%$ 햄육만을 사용한 대조구에 비해 $\mathrm{T} 1$ 의 보수력 값이 높게 나타난 것에 미루어 $40 \%$ 회수단백질 대체시 제품내 보수력을 향상시킬 것으로 판단되나, 처리구들간에 유의적인 차이가 나타나지 않아 $40 \%$ 회수단백질이 제품내 보수력 향상엔 기여하진 못하였다( $\mathrm{p}>0.05)$. 4주차 또한 대조구와 처리구들 간에 유의적인 차이가 나타나지 않았다 $(\mathrm{p}>0.05)$. 저장기간별 보수 력 측정 결과, $\mathrm{T} 7$ 의 경우 저장 4주차에 유의적으로 증가하였다. 이 등 (2004)은 CLA가 축전된 돈육으로 이용한 프레스햄 제조시 2주 급여구에 비해 4주 급여 샘플에서 제품 내 수분 함량의 감소로 이 어졌다. 따라서 본 연구에서도 CLA 첨가구에서 보수력의 감소가
예상되었으나 최대 $0.1 \%$ 첨가에 따른 결과 보수력의 변화에 영향 하지 않았으며, 분말 형태의 동충하초 및 누에고치 첨가 또한 보수 력에 영향하지 못하였다. 가열감량 결과, 대조구, $40 \%$ 회수단백질 대체구인 $\mathrm{T} 1$ 과 기능성 물질을 각각 첨가한 $\mathrm{T} 2, \mathrm{~T} 3$ 및 $\mathrm{T} 4$ 는 저장 기간에 따른 차이가 없는 반면, 2 가지 이상의 기능성 물질을 혼합 첨가한 $\mathrm{T} 5, \mathrm{~T} 6$ 및 $\mathrm{T} 7$ 은 저장 4주차에 높은 가열감량을 보여주었 다 $(\mathrm{p}<0.05)$. 또한 저장 0 주차에는 처리구들간에 유의적인 차이가 나타나지 않았으나 저장 4 주차에는 대조구에 비해 $40 \%$ 회수단백질 처리구에서 낮은 경향을 보였으며, 특히 $0.1 \%$ 동충하초 및 누에고 치 처리구인 $\mathrm{T} 2$ 및 $\mathrm{T} 3$ 에서 낮게 나타났다 $(\mathrm{p}<0.05)$. 명도의 경우, 저장 0주차와 4주차 모두 대조구에 비해 처리구에서 높게 나타났 다 $(\mathrm{P}<0.05)$. Park과 Morrissey (2000)이 “회수단백질은 근장단백 질, 지질 및 비단백태 질소 화합물 등을 제거하고 근원섬유단백질 만을 농축한 후 냉동 변성방지제를 혼합,한 것으로 축육 제품에 비 해 밝은 색을 가진다. 또한 Park 등 (2003)의 닭가슴살과 돈육 뒷 다리 부위간 품종간의 비교에서 닭가슴살을 활용한 수리미의 색이 돈육 뒷다리 부위를 활용하여 제조된 수리미보다 색이 밝게 나타났 다고 보고하였는데 닭가슴살에 비해 돈육 뒷다리부위가 적색육에 가깝기 때문인 것으로 판단된다. 또한 수리미 품질을 결정하는 중 요한 요인 중 하나인 색의 경우, 백색도 및 명도 값이 높을수록 품 질이 좋은 것으로 평가된다(Oehiai 등, 2001). 그러나 수리미 자체 의 품질 특성과 달리 일반 축육제품 생산을 위한 기초자료 활용면

Table 3. Effect of functional ingredients on $\mathrm{pH}$, water holding capacity $(\mathrm{WHC})$, cooking loss and color (ClE $\left.\mathrm{L}^{*}\right)$ of sausage manufactured by spent hens breast recovered protein during storage at $4{ }^{\circ} \mathrm{C}$

\begin{tabular}{lcccccccc}
\hline & \multicolumn{7}{c}{ Treatments $^{1)}$} \\
\cline { 2 - 9 } Items & $\mathrm{C}$ & $\mathrm{T} 1$ & $\mathrm{~T} 2$ & $\mathrm{~T} 3$ & $\mathrm{~T} 4$ & $\mathrm{~T} 5$ & $\mathrm{~T} 6$ & $\mathrm{~T} 7$ \\
\hline \hline Storage period $(0$ wk) & & & & & & \\
$\mathrm{pH}$ & $5.96 \pm 0.02^{\mathrm{Db}}$ & $6.12 \pm 0.01^{\mathrm{Ab}}$ & $6.11 \pm 0.01^{\mathrm{ABCb}}$ & $6.12 \pm 0.01^{\mathrm{Ab}}$ & $6.12 \pm 0.01^{\mathrm{Ab}}$ & $6.12 \pm 0.01^{\mathrm{Ab}}$ & $6.09 \pm 0.02^{\mathrm{Bb}}$ & $6.01 \pm 0.01^{\mathrm{Cb}}$ \\
WHC (\%) & $77.51 \pm 3.36^{\mathrm{ABC}} 81.40 \pm 9.55^{\mathrm{A}}$ & $74.50 \pm 6.44^{\mathrm{ABC}} 78.86 \pm 7.24^{\mathrm{AB}}$ & $75.40 \pm 4.90^{\mathrm{ABC}}$ & $72.21 \pm 2.94^{\mathrm{ABC}} 69.09 \pm 3.80^{\mathrm{BC}}$ & $67.88 \pm 0.70^{\mathrm{Cb}}$ \\
Cooking loss (\%) $15.89 \pm 5.73$ & $12.51 \pm 0.78$ & $12.45 \pm 0.82$ & $12.97 \pm 1.25$ & $13.11 \pm 0.63$ & $12.78 \pm 0.25^{\mathrm{b}}$ & $12.03 \pm 1.03^{\mathrm{b}}$ & $12.83 \pm 1.28^{\mathrm{b}}$ \\
Lightness ( $\left.\mathrm{L}^{*}\right)$ & $78.12 \pm 0.40^{\mathrm{C}}$ & $80.46 \pm 0.31^{\mathrm{B}}$ & $80.68 \pm 0.10^{\mathrm{B}}$ & $82.03 \pm 0.10^{\mathrm{A}}$ & $80.73 \pm 0.74^{\mathrm{B}}$ & $80.92 \pm 0.23^{\mathrm{B}}$ & $81.88 \pm 0.64^{\mathrm{A}}$ & $81.03 \pm 0.61^{\mathrm{B}}$ \\
\hline
\end{tabular}

Storage period (4 wks)

$\mathrm{pH} \quad 6.01 \pm 0.02^{\mathrm{Ca}} \quad 6.19 \pm 0.01^{\mathrm{Aa}} \quad 6.16 \pm 0.03^{\mathrm{ABa}} \quad 6.17 \pm 0.01^{\mathrm{Aa}} \quad 6.19 \pm 0.01^{\mathrm{ABa}} \quad 6.17 \pm 0.03^{\mathrm{ABa}} \quad 6.14 \pm 0.02^{\mathrm{Ba}} \quad 6.15 \pm 0.01^{\mathrm{Ba}}$ $\mathrm{WHC}(\%) \quad 73.68 \pm 3.03^{\mathrm{AB}} \quad 76.98 \pm 3.94^{\mathrm{A}} \quad 66.91 \pm 3.74^{\mathrm{B}} \quad 74.91 \pm 1.35^{\mathrm{AB}} 72.41 \pm 2.19^{\mathrm{AB}} \quad 72.51 \pm 2.63^{\mathrm{AB}} \quad 71.84 \pm 9.76^{\mathrm{AB}} \quad 71.67 \pm 1.32^{\mathrm{ABa}}$ Cooking loss (\%) $15.57 \pm 1.03^{\mathrm{AB}} \quad 13.87 \pm 1.04^{\mathrm{BCD}} 13.11 \pm 1.05^{\mathrm{CD}} \quad 12.35 \pm 1.17^{\mathrm{D}} \quad 14.75 \pm 1.61^{\mathrm{ABC}} 14.42 \pm 0.66^{\mathrm{ABCDa}} 15.41 \pm 0.66^{\mathrm{ABa}} 16.27 \pm 1.34^{\mathrm{Aa}}$ Lightness $\left(\mathrm{L}^{*}\right) \quad 78.02 \pm 0.54^{\mathrm{D}} \quad 80.96 \pm 0.36^{\mathrm{BC}} \quad 80.21 \pm 1.03^{\mathrm{C}} \quad 81.71 \pm 0.34^{\mathrm{AB}} 82.05 \pm 0.64^{\mathrm{A}} \quad 81.13 \pm 0.33^{\mathrm{ABC}} 81.63 \pm 0.56^{\mathrm{AB}} \quad 81.17 \pm 0.23^{\mathrm{ABC}}$

\footnotetext{
${ }^{1)}$ Control pork sausage, T1: $40 \%$ of pork was replaced with $\mathrm{pH}$ adjusted breast muscle of spent laying hen (recovered protein), T2: $40 \%$ recovered protein from spend laying hen with 0.1\% Cordyceps ochraceostromat powder, T3: $40 \%$ recovered protein from spend laying hen with $0.1 \%$ silkworm cocoon powder, T4: $40 \%$ recovered protein from spend laying hen with $0.1 \%$ CLA, T5: $40 \%$ recovered protein from spend laying hen with $0.05 \%$ Cordyceps ochraceostromat $+0.05 \%$ silkworm cocoon powder, T6: $40 \%$ recovered protein from spend laying hen with $0.05 \%$ Cordyceps ochraceostromat $+0.05 \%$ CLA, and T7: $40 \%$ recovered protein from spend laying hen with $0.05 \%$ silkworm cocoon powder $+0.05 \%$ CLA. $n=3$.

A-D Means with different superscript capital letters in a row are significantly different $(\mathrm{p}<0.05)$.

a-b Means with different superscript small letters in a column are significantly different $(p<0.05)$.
} 
에서 $40 \%$ 폐계가슴살 회수단백질 대체는 기존의 축육제품에 비해 밝은 육색을 나타냄을 확인하였다. 이러한 밝은 육색은 육 및 육제 품의 선호도를 떨어뜨릴 우려가 있어 관능평가 결과가 뒷받침 되어 야 할 것으로 판단된다.

\section{3. 조직적 특성}

돈육 소시지의 저장 중 조직적 특성 변화는 Table 4에서 나타내 었다. 경도, 응집성, 검성 및 씹힘성에서 저장 0 일차에 비해 저장 4 주차로 저장기간이 증가할수록 $\mathrm{T} 3, \mathrm{~T} 5$ 및 $\mathrm{T} 6$ 에서 높게 나타났다 $(\mathrm{p}<0.05)$. 처리구간 비교 시, 저장 0 주차와 4 주차 모두 대조구에 비해 처리구에서 연도와 씹힘성이 낮게 나타났다 $(\mathrm{p}<0.05)$. 응집성 의 경우, 0 주차에는 기능성 물질이 첨가된 $\mathrm{T} 3, \mathrm{~T} 4, \mathrm{~T} 5$ 및 $\mathrm{T} 6$ 에서 낮게 나타났으며, 저장 4 주차엔 대조구에 비해 $40 \%$ 회수단백질 대 체구인 $\mathrm{T} 1, \mathrm{~T} 4$ 및 $\mathrm{T} 6$ 에서 대조구보다 낮게 나타났다 $(\mathrm{p}<0.05)$. 또한 저장 0 주차에 탄력성은 모든 처리구간에 유의적인 차이가 나 타나지 않았으나 검성의 경우 대조구에서 비해 처리구에서 낮게 나 타났다. 따라서 경도 등의 조직감 항목에서 대조구보다 $40 \%$ 회수
단백질 대체구인 $\mathrm{T} 1$ 에서 낮게 나타나 회수단백질 대체시 연한 조 직감을 형성할 것으로 판단된다. Park 등 (2003)은 응집성은 수리 미 조직특성을 측정하는 척도로 겔 강도 및 조직감 수치가 높을수 록 수리미 단백질 조직이 안정적이라 하였다. 또한 Jin 등 (2008b) 은 원료육 비율을 달리한 게맛소시지에서 축육으로부터 회수된 수 리미의 대체 수준이 높을수록 조직감을 높이며 기호도의 변화를 가 져온다. 따라서 $40 \%$ 노폐계육을 활용한 회수단백질의 대체는 조직 감을 떨어뜨려 소비자의 기호도에 영향을 미칠 것으로 판단되나 수 리미 자체의 조직감과 달리 저지방 축육 소시지에서 연한 조직감을 형성할수록 기호도를 높인다는 보고(Yang 등, 2007)와 같이 회수 단백질을 활용한 축육 소시지의 조직감과 더불어 기호도와 부합된 수준에서 회수단백질의 대체가 결정되리라 판단된다.

4. 지방산패도(TBARS), 휘발성염기태질소(VBN) 및 미 생물 수 측정

저장 중 지방산패도, 휘발성염기태질소 및 총균수 측정 결과는 Table 5와 같다. TBARS 수치는 육과 육제품의 지질산화 정도를

Table 4. Effect of functional ingredients on TPA (texture profile analysis) of sausage manufactured by spent hens breast recovered protein during storage at $4{ }^{\circ} \mathrm{C}$

\begin{tabular}{|c|c|c|c|c|c|c|c|c|}
\hline \multirow{2}{*}{ Items } & \multicolumn{8}{|c|}{ Treatments ${ }^{1)}$} \\
\hline & $\mathrm{C}$ & $\mathrm{T} 1$ & $\mathrm{~T} 2$ & $\mathrm{~T} 3$ & T4 & T5 & T6 & $\mathrm{T} 7$ \\
\hline \multicolumn{9}{|l|}{ Storage period $(0 \mathrm{wk})$} \\
\hline Hardness (kg) & $0.39 \pm 0.04^{\mathrm{A}}$ & $0.36 \pm 0.02^{\mathrm{BCD}}$ & $0.23 \pm 0.01^{\mathrm{Db}}$ & $0.23 \pm 0.02^{\mathrm{Db}}$ & $0.29 \pm 0.01^{\mathrm{B}}$ & $0.27 \pm 0.01^{\mathrm{BCb}}$ & $0.25 \pm 0.02^{\mathrm{CD}}$ & $0.24 \pm 0.02^{\mathrm{CD}}$ \\
\hline Cohesiveness (\%) & $0.65 \pm 0.03^{\mathrm{A}}$ & $0.65 \pm 0.06^{\mathrm{A}}$ & $0.60 \pm 0.03^{\mathrm{AB}}$ & $0.52 \pm 0.01^{\mathrm{CDb}}$ & $0.59 \pm 0.01^{\mathrm{B}}$ & $0.48 \pm 0.02^{\mathrm{Db}}$ & $0.56 \pm 0.01^{\mathrm{BCb}}$ & $0.60 \pm 0.03^{\mathrm{AB}}$ \\
\hline Springiness (mm) & $1.00 \pm 0.00$ & $1.01 \pm 0.04$ & $1.00 \pm 0.01$ & $1.00 \pm 0.00$ & $1.00 \pm 0.00$ & $1.00 \pm 0.00$ & $1.00 \pm 0.00$ & $1.00 \pm 0.00$ \\
\hline Gumminess (kg) & $0.25 \pm 0.02^{\mathrm{A}}$ & $0.16 \pm 0.01^{\mathrm{BC}}$ & $0.14 \pm 0.01^{\mathrm{DE}}$ & $0.12 \pm 0.01^{\mathrm{Eb}}$ & $0.18 \pm 0.01^{\mathrm{B}}$ & $0.13 \pm 0.01^{\mathrm{DEb}}$ & $0.14 \pm 0.01^{\mathrm{CDb}}$ & $0.14 \pm 0.02^{\mathrm{CD}}$ \\
\hline Chewiness (kg*mm) & $0.25 \pm 0.02^{\mathrm{A}}$ & $0.17 \pm 0.01^{\mathrm{B}}$ & $0.14 \pm 0.01^{\mathrm{CD}}$ & $0.12 \pm 0.01^{\mathrm{Db}}$ & $0.17 \pm 0.01^{\mathrm{B}}$ & $0.13 \pm 0.01^{\mathrm{CDb}}$ & $0.14 \pm 0.01^{\mathrm{Cb}}$ & $0.14 \pm 0.01^{\mathrm{C}}$ \\
\hline \multicolumn{9}{|l|}{ Storage period (4 wks) } \\
\hline Hardness (kg) & $0.36 \pm 0.00^{\mathrm{A}}$ & $0.27 \pm 0.01^{\mathrm{DE}}$ & $0.25 \pm 0.01^{\mathrm{Fa}}$ & $0.28 \pm 0.1^{\mathrm{CDa}}$ & $0.30 \pm 0.01^{\mathrm{B}}$ & $0.29 \pm 0.00^{\mathrm{BCa}}$ & $0.27 \pm 0.01^{\mathrm{E}}$ & $0.25 \pm 0.01^{\mathrm{F}}$ \\
\hline Cohesiveness (\%) & $0.67 \pm 0.07^{\mathrm{A}}$ & $0.58 \pm 0.01^{\mathrm{BC}}$ & $0.61 \pm 0.03^{\mathrm{ABC}}$ & $0.61 \pm 0.03^{\mathrm{ABCa}}$ & $0.60 \pm 0.01^{\mathrm{BC}}$ & $0.62 \pm 0.03^{\mathrm{ABCa}}$ & ${ }^{\mathrm{a}} 0.64 \pm 0.02^{\mathrm{ABa}}$ & $0.57 \pm 0.03^{\mathrm{C}}$ \\
\hline Springiness (mm) & $1.01 \pm 0.02$ & $1.01 \pm 0.02$ & $1.01 \pm 0.01$ & $1.01 \pm 0.02$ & $1.01 \pm 0.02$ & $1.00 \pm 0.00$ & $1.00 \pm 0.00$ & $1.03 \pm 0.05$ \\
\hline Gumminess (kg) & $0.24 \pm 0.03$ & $0.16 \pm 0.01$ & $0.15 \pm 0.01$ & $0.17 \pm 0.01^{\mathrm{a}}$ & $0.18 \pm 0.01$ & $0.18 \pm 0.01^{\mathrm{a}}$ & $0.17 \pm 0.01^{\mathrm{a}}$ & $0.14 \pm 0.01$ \\
\hline Chewiness $\left(\mathrm{kg}^{*} \mathrm{~mm}\right)$ & $0.25 \pm 0.03^{\mathrm{A}}$ & $0.16 \pm 0.01^{\mathrm{BCD}}$ & $0.15 \pm 0.01^{\mathrm{CD}}$ & $0.17 \pm 0.01^{\mathrm{BCa}}$ & $0.18 \pm 0.02^{\mathrm{B}}$ & $0.18 \pm 0.01^{\mathrm{Ba}}$ & $0.17 \pm 0.01^{\mathrm{BCa}}$ & $0.15 \pm 0.02^{\mathrm{D}}$ \\
\hline \multicolumn{9}{|c|}{$\begin{array}{l}\text { 1) Control pork sausage, T1: } 40 \% \text { of pork was replaced with } \mathrm{pH} \text { adjusted breast muscle of spent laying hen (recovered protein), T2: } \\
40 \% \text { recovered protein from spend laying hen with } 0.1 \% \text { Cordyceps ochraceostromat powder, T3: } 40 \% \text { recovered protein from spend } \\
\text { laying hen with } 0.1 \% \text { silkworm cocoon powder, T4: } 40 \% \text { recovered protein from spend laying hen with } 0.1 \% \text { CLA, T5: } 40 \% \\
\text { recovered protein from spend laying hen with } 0.05 \% \text { Cordyceps ochraceostromat }+0.05 \% \text { silkworm cocoon powder, T6: } 40 \% \\
\text { recovered protein from spend laying hen with } 0.05 \% \text { Cordyceps ochraceostromat }+0.05 \% \text { CLA, and T7: } 40 \% \text { recovered protein from } \\
\text { spend laying hen with } 0.05 \% \text { silkworm cocoon powder }+0.05 \% \text { CLA. } n=3 \text {. }\end{array}$} \\
\hline
\end{tabular}


Jin et al. ; Quality Properties of Functional Ingredients in Pork Sausage Manufactured with Recovered Protein

Table 5. Effect of functional ingredients on TBARS, VBN and microorganism of sausage manufactured by spent hens breast recovered protein during storage at $4^{\circ} \mathrm{C}$

\begin{tabular}{|c|c|c|c|c|c|c|}
\hline \multirow{2}{*}{ Items } & \multicolumn{6}{|c|}{ Treatments $^{1)}$} \\
\hline & $\mathrm{T} 1$ & $\mathrm{~T} 3$ & $\mathrm{~T} 4$ & T5 & T6 & $\mathrm{T} 7$ \\
\hline \multicolumn{7}{|l|}{ Storage period $(0 \mathrm{wk})$} \\
\hline TBARS (mg/100g) & $1.85 \pm 0.06^{\mathrm{BC}}$ & $2.06 \pm 0.03^{\mathrm{Aa}}$ & $1.87 \pm 0.03^{\mathrm{BCa}}$ & $1.83 \pm 0.03^{\mathrm{BCa}}$ & $1.86 \pm 0.07^{\mathrm{BCa}}$ & $1.87 \pm 0.02^{\mathrm{BCa}}$ \\
\hline VBN (mg\%) & $82.13 \pm 8.40^{\mathrm{ABb}} \quad 76.53 \pm 2.80^{\mathrm{ABb}}$ & $75.13 \pm 8.52^{\mathrm{ABb}} 72.80 \pm 7.05^{\mathrm{ABCb}}$ & $75.60 \pm 4.27^{\mathrm{ABb}}$ & $58.61 \pm 3.08^{\mathrm{Cb}}$ & $68.13 \pm 2.60^{\mathrm{BCb}}$ & $86.33 \pm 18.20^{\mathrm{A}}$ \\
\hline TPC (log CFU) & $1.90 \pm 0.05^{\mathrm{CDb}}$ & $\quad 2.04 \pm 0.16^{\mathrm{BCb}} \quad 1.93 \pm 0.06^{\mathrm{CDb}}$ & $1.56 \pm 0.07^{\mathrm{Eb}}$ & $2.05 \pm 0.06^{\mathrm{BCb}}$ & $2.48 \pm 0.08^{\mathrm{Ab}}$ & $2.23 \pm 0.05^{\mathrm{ABb}}$ \\
\hline \multicolumn{7}{|l|}{ Storage period (4 wks) } \\
\hline TBARS (mg/100g) & $1.76 \pm 0.08^{\mathrm{ABC}}$ & ${ }^{\mathrm{C}} 1.77 \pm 0.14^{\mathrm{AB}} \quad 1.79 \pm 0.11^{\mathrm{Ab}}$ & $1.60 \pm 0.02^{\mathrm{Cb}}$ & $1.58 \pm 0.05^{\mathrm{Cb}}$ & $1.62 \pm 0.06^{\mathrm{BCb}}$ & $1.80 \pm 0.01^{\mathrm{Ab}}$ \\
\hline $\mathrm{VBN}(\mathrm{mg} \%)$ & $143.50 \pm 21.00^{\mathrm{Aa}} 117.18 \pm 5.32^{\mathrm{Ba}}$ & $96.37 \pm 1.62^{\mathrm{Ba}} \quad 96.32 \pm 1.82^{\mathrm{Ba}}$ & $143.03 \pm 8.60^{\mathrm{Aa}}$ & $113.17 \pm 1.62^{\mathrm{Ba}}$ & $101.22 \pm 16.01^{\mathrm{Ba}}$ & $110.18 \pm 9.12^{\mathrm{B}}$ \\
\hline TPC (log CFU) & $6.04 \pm 0.03^{\mathrm{Fa}} \quad 6.49 \pm 0.01^{\mathrm{Ba}}$ & $6.15 \pm 0.03^{\mathrm{Ea}}$ & $6.59 \pm 0.03^{\mathrm{Aa}}$ & $6.36 \pm 0.02^{\mathrm{Ca}}$ & $6.47 \pm 0.13^{\mathrm{Ba}}$ & $6.37 \pm 0.07^{\mathrm{Ca}}$ \\
\hline \multicolumn{7}{|c|}{$\begin{array}{l}\text { Control pork sausage, } \mathrm{T} 1: 40 \% \text { of pork was replaced with } \mathrm{pH} \text { adjusted breast muscle of spent laying hen (recovered protein), T2: } \\
40 \% \text { recovered protein from spend laying hen with } 0.1 \% \text { Cordyceps ochraceostromat powder, T3: } 40 \% \text { recovered protein from spend } \\
\text { laying hen with } 0.1 \% \text { silkworm cocoon powder, T4: } 40 \% \text { recovered protein from spend laying hen with } 0.1 \% \text { CLA, T5: } 40 \% \\
\text { recovered protein from spend laying hen with } 0.05 \% \text { Cordyceps ochraceostromat }+0.05 \% \text { silkworm cocoon powder, T6: } 40 \% \\
\text { recovered protein from spend laying hen with } 0.05 \% \text { Cordyceps ochraceostromat }+0.05 \% \text { CLA, and T7: } 40 \% \text { recovered protein from } \\
\text { spend laying hen with } 0.05 \% \text { silkworm cocoon powder }+0.05 \% \text { CLA. } n=3 \text {. } \\
\text { A-F } \text { Means with different superscript capital letters in a row are significantly different }(\mathrm{p}<0.05) \text {. } \\
\text {-b Means with different superscript small letters in a column are significantly different }(\mathrm{p}<0.05) \text {. }\end{array}$} \\
\hline
\end{tabular}

나타내며 TBARS 값은 저장기간이 길어질수록 증가하는 것이 일 반적이다(Witte 등, 1970). 그러나 지방산패도의 경우, 저장 0주차 에 비해 4 주째의 처리구들에서 $\mathrm{TBARS}$ 값이 감소하며 $(\mathrm{p}<0.05)$, 대조구와 $\mathrm{T} 1, \mathrm{~T} 2$ 구는 저장 0 주차와 4 주차간에 값의 차이 또한 나 타나지 않았다. 처리구들간의 비교 시 저장 0 주차에는 $\mathrm{T} 3$ 에서 대 조구에 비해 높은 TBARS 값을 보였으며, 저장 4주차에는 T4, T5 및 $\mathrm{T} 6$ 에서 대조구보다 낮은 TBARS 값을 보였다 $(\mathrm{p}<0.05)$. Jin 등 (2007a)은 냉동변성방지제를 첨가한 닭가슴살 수리미의 TBARS 값은 저장 15 일째까지는 감소하다가 30 일째에는 증가되는 등 Alaska pollack 및 닭가슴살을 활용한 냉동 수리미의 지질 산화가 저장 15 일째 이후에 급격히 발생됨을 보고하였다. 또한 Jin 등 (2007b)은 폐계 가슴살을 활용한 축육 소시지 제조에서 폐계 가슴 살 회수단백질의 활용은 TBARS 값을 감소 시킨다고 보고한 바 있다. 따라서 저장 기간이 증가할수록 TBARS 값의 증가가 일반 적이나, 노폐계육 회수단백질을 활용한 축육 소시지 형태로의 제품 제조시 TBARS 값의 증가를 억제하며, 기능성 물질 첨가 또한 축 육 소시지의 저장성 향상에 기여할 것으로 사료된다.

누에고치와 $\mathrm{CLA}$ 를 각각 $0.05 \%$ 첨가한 $\mathrm{T} 7$ 구는 저장기간에 따 른 차이를 없었으나, $\mathrm{T} 7$ 을 제외한 모든 처리구들은 저장기간이 증 가할수록 높은 $\mathrm{VBN}$ 값을 나타내었다 $(\mathrm{p}<0.05)$. 또한 처리구들간 비교시, 저장 0 일차엔 $\mathrm{T} 5$ 만이 대조구에 비해 낮게 나타났으나 저 장 4주차에는 $\mathrm{T} 4$ 를 제외한 모든 처리구에서 대조구보다 낮은 $\mathrm{VBN}$ 값을 나타내었다 $(\mathrm{p}<0.05)$. 또한 저장 4 주차에 대조구에 비해
$40 \%$ 회수단백질을 대체한 $\mathrm{T} 1$ 에서 유의적으로 낮은 $\mathrm{VBN}$ 값을 보 여 회수단백질의 활용은 저장 말기의 축육제품의 $\mathrm{VBN}$ 값을 떨어 뜨릴 것으로 판단된다.

총균수는 저장기간이 증가할수록 모든 처리구에서 높은 수치를 보이며, 저장 말기 즉, 4 주차에 대조구보다 모든 처리구에서 높은 총균수 값을 나타내었다 $(\mathrm{p}<0.05)$. 특히 대조구에 비해 $40 \%$ 회수단 백질 대체(T1)는 총균수를 증가시키며, 동충하초 및 $\mathrm{CLA}$ 를 각각 $0.05 \%$ 씩 첨가한 $\mathrm{T} 6$ 및 $\mathrm{CLA}$ 를 첨가한 $\mathrm{T} 4$ 에서 $\mathrm{T} 1$ 보다 높거나 같 은 값을 보여 CLA 단독 첨가를 통한 제품내 총균수 감소 효과뿐 만 아니라 동충하초 및 CLA를 혼합 첨가는 미생물 수 감소에 효 과가 없는 것으로 판단되다. 따라서 $40 \%$ 회수단백질과 기능성 물 질의 첨가는 저장 말기의 축육 소시지 제품의 총균수에 영향을 미 치지 못하였으나, $100 \%$ 햄육만을 사용한 대조구에 비해 VBN 값 을 낮출 뿐만 아니라 저장 중 지질산화를 억제시키는 것으로 나타 났다.

5. 관능평가

기능성 물질의 첨가가 노폐계육 회수단백질을 활용한 돈육 소시 지의 저장 중 관능평가 결과, 저장기간이 경과할수록 모든 처리구 의 다즙성 항목에서 낮은 점수를 획득하였으나 $(\mathrm{p}<0.05)$, 다른 평가 항목들은 저장기간에 따른 차이가 발견되지 않았다. 또한 저장 0 주 차의 모든 관능평가 항목에서 처리구들간의 차이가 나타나지 않았 
Table 6. Effect of functional ingredients on sensory evaluations of sausage manufactured by spent hens breast recovered protein during storage at $4^{\circ} \mathrm{C}$

\begin{tabular}{|c|c|c|c|c|c|c|c|c|}
\hline \multirow{2}{*}{ Items } & \multicolumn{8}{|c|}{ Treatments ${ }^{1)}$} \\
\hline & $\mathrm{C}$ & $\mathrm{T} 1$ & $\mathrm{~T} 2$ & $\mathrm{~T} 3$ & $\mathrm{~T} 4$ & $\mathrm{~T} 5$ & T6 & $\mathrm{T} 7$ \\
\hline \multicolumn{9}{|l|}{ Storage period ( 0 wk) } \\
\hline Color & $6.00 \pm 0.89$ & $6.10 \pm 0.49$ & $5.83 \pm 1.17$ & $6.17 \pm 0.75$ & $5.92 \pm 1.02$ & $6.00 \pm 0.89$ & $5.83 \pm 1.17$ & $6.00 \pm 1.09$ \\
\hline Aroma & $6.50 \pm 1.00$ & $6.43 \pm 0.75$ & $6.35 \pm 0.62$ & $6.31 \pm 0.82$ & $6.33 \pm 1.08$ & $6.14 \pm 0.92$ & $6.42 \pm 0.92$ & $6.50 \pm 0.55^{\mathrm{a}}$ \\
\hline Flavor & $6.83 \pm 0.75$ & $6.33 \pm 0.52$ & $6.43 \pm 0.53$ & $6.43 \pm 0.52$ & $6.25 \pm 0.42$ & $6.33 \pm 0.52$ & $6.33 \pm 0.52$ & $6.42 \pm 0.66$ \\
\hline Tenderness & $6.67 \pm 0.41$ & $6.66 \pm 70.42$ & $6.33 \pm 0.82$ & $6.34 \pm 0.52$ & $6.50 \pm 0.55$ & $6.17 \pm 0.75$ & $6.33 \pm 0.52$ & $6.33 \pm 0.52$ \\
\hline Juiciness & $6.50 \pm 0.84^{\mathrm{a}}$ & $6.83 \pm 0.75^{\mathrm{a}}$ & $6.83 \pm 0.75^{\mathrm{a}}$ & $7.00^{\mathrm{a}}$ & $73.00 \pm 0.63^{\mathrm{a}}$ & $7.00 \pm 0.63^{\mathrm{a}}$ & $7.00 \pm 0.63^{\mathrm{a}}$ & $7.17 \pm 0.75^{\mathrm{a}}$ \\
\hline Overall acceptability & $6.67 \pm 0.82$ & $6.50 \pm 0.55$ & $6.33 \pm 0.82$ & $6.42 \pm 0.92$ & $6.58 \pm 0.66$ & $6.58 \pm 0.66$ & $6.50 \pm 0.55$ & $6.58 \pm 0.49$ \\
\hline \multicolumn{9}{|l|}{ Storage period (4 wks) } \\
\hline Color & $6.75 \pm 0.42^{\mathrm{A}}$ & $6.18 \pm 0.86^{\mathrm{AB}}$ & $6.08 \pm 0.66^{\mathrm{AB}}$ & $5.98 \pm 0.93^{\mathrm{B}}$ & $6.00 \pm 0.60^{\mathrm{B}}$ & $6.17 \pm 0.41^{\mathrm{AB}}$ & $6.17 \pm 0.41^{\mathrm{AB}}$ & $6.17 \pm 0.41^{\mathrm{AB}}$ \\
\hline Aroma & $5.83 \pm 0.81$ & $5.50 \pm 0.63$ & $5.58 \pm 0.49$ & $5.75 \pm 0.42$ & $5.75 \pm 0.41$ & $5.75 \pm 0.42$ & $5.58 \pm 0.48$ & $5.75 \pm 0.42^{\mathrm{b}}$ \\
\hline Flavor & $6.17 \pm 0.40^{\mathrm{A}}$ & $6.00^{\mathrm{AB}}$ & $5.75 \pm 0.42^{\mathrm{B}}$ & $6.00^{\mathrm{AB}}$ & $6.00^{\mathrm{AB}}$ & $6.00^{\mathrm{AB}}$ & $5.92 \pm 0.20^{\mathrm{AB}}$ & $5.83 \pm 0.41^{\mathrm{AB}}$ \\
\hline Tenderness & $6.08 \pm 0.80$ & $6.25 \pm 0.42$ & $6.33 \pm 0.52$ & $6.33 \pm 0.52$ & $6.17 \pm 0.52$ & $6.33 \pm 0.52$ & $6.17 \pm 0.75$ & $6.08 \pm 0.66$ \\
\hline Juiciness & $5.58 \pm 0.49^{\mathrm{b}}$ & $5.75 \pm 0.42^{\mathrm{b}}$ & $5.83 \pm 0.41^{\mathrm{b}}$ & $5.67 \pm 0.61^{\mathrm{b}}$ & $5.75 \pm 0.52^{\mathrm{b}}$ & $5.83 \pm 0.52^{\mathrm{b}}$ & $5.50 \pm 0.63^{\mathrm{b}}$ & $5.50 \pm 0.63^{\mathrm{b}}$ \\
\hline Overall acceptability & $6.00 \pm 0.63$ & $5.83 \pm 0.52$ & $6.00 \pm 0.32$ & $6.00 \pm 0.45$ & $6.00 \pm 0.45$ & $6.00 \pm 0.45$ & $5.83 \pm 0.41$ & $6.00 \pm 0.45$ \\
\hline
\end{tabular}

${ }^{1)}$ Control pork sausage, T1: 40\% of pork was replaced with $\mathrm{pH}$ adjusted breast muscle of spent laying hen (recovered protein), T2: $40 \%$ recovered protein from spend laying hen with $0.1 \%$ Cordyceps ochraceostromat powder, T3: $40 \%$ recovered protein from spend laying hen with $0.1 \%$ silkworm cocoon powder, T4: $40 \%$ recovered protein from spend laying hen with $0.1 \%$ CLA, T5: $40 \%$ recovered protein from spend laying hen with $0.05 \%$ Cordyceps ochraceostromat $+0.05 \%$ silkworm cocoon powder, T6: $40 \%$ recovered protein from spend laying hen with $0.05 \%$ Cordyceps ochraceostromat $+0.05 \%$ CLA, and T7: $40 \%$ recovered protein from spend laying hen with $0.05 \%$ silkworm cocoon powder $+0.05 \%$ CLA. $n=3$.

A-B Means with different superscript capital letters in a row are significantly different $(\mathrm{p}<0.05)$.

a-b Means with different superscript small letters in a column are significantly different $(p<0.05)$.

Color ( 1 to 3 pale, 4 to 6 normal, 7 to 9: dark), aroma (1 to 3 weak, 4 to 6 moderate, 7 to 9: strong), flavor (1 to 3 weak, 4 to 6 moderate, 7 to 9: strong), tenderness ( 1 to 3 tough, 4 to 6 moderate, 7 to 9 : tender), juiciness ( 1 to 3 small, 4 to 6 moderate, 7 to 9 : large) and overall acceptability (1 to 3 dislike, 4 to 6 moderate, 7 to 9 : like).

으나 저장 4 주차에는 $40 \%$ 회수단백질 대체구에 $0.1 \%$ 누에고치 분말 첨가구(T3)와 CLA 첨가구인(T4)에서 대조구에 비해 낮은 육 색 선호도를 획득하였다. 또한 풍미 항목에선 $40 \%$ 회수단백질 대 체구에 $0.1 \%$ 동충하초 분말 첨가구인 $\mathrm{T} 2$ 에서 대조구에 비해 낮은 점수를 획득하였다. 그러나 저장 4 주차의 육색과 풍미에서의 낮은 점수에도 불구하고 전체적인 기호도에 영향을 미치지 못하여 모든 처리구에서 동일한 점수를 획득하였다 $(\mathrm{p}>0.05)$. 따라서 $\operatorname{Jin}$ 등 (2008b)은 새로운 조직 형성을 위한 게맛 소시지 제조시 닭가슴살 회수단백질의 대체 $20 \%$ 까지는 기호도의 차이를 보이지 못하나 $36 \%$ 이상의 대체시 낮은 기호도를 가져왔다고 보고한 바 있다. 새 로운 조직 특성을 갖는 제품일지라도 소비자의 기호도와 부합되어 야 하는바, $40 \%$ 의 대체 수준은 돈육 소시지의 기호도를 떨어뜨릴
것으로 판단되었으나 오히려 기호도 값의 차이를 보이지 않아 노폐 계육 회수단백질을 활용한 축육 소시지 형태의 제품 개발 및 동충 하초, 누에고치 및 CLA를 활용한 기능성 육제품 개발 또한 가능 할 것으로 판단된다.

$$
\text { 요 약 }
$$

기능성 물질의 첨가가 노폐계육단백질을 활용한 돈육 소시지의 저장 중 품질 및 저장성에 미치는 영향에 대해 알아보고자, 햄육만 을 사용한 대조구에 $40 \%$ 기계발골육 회수단백질을 활용한 $\mathrm{T} 1$, $40 \%$ 회수단백질에 $0.1 \%$ 동충하초 분말을 첨가한 $\mathrm{T} 2,0.1 \%$ 누에 고치 분말을 첨가한 $\mathrm{T} 3,0.1 \% \mathrm{CLA}$ 를 첨가한 $\mathrm{T} 4$ 및 $0.05 \%$ 씩 동 
충하초, 누에고치 및 $\mathrm{CLA}$ 를 각각 첨가하여 $\mathrm{T} 5, \mathrm{~T} 6$ 및 $\mathrm{T} 7$ 으로 분 류하여 4주간 저장하였다. 저장 말기 $\mathrm{T} 4$ 를 제외하곤 수분 함량은 차이가 없었으며, 단백질 함량 결과, 처리구에서 높은 경향을 보이 며, 지방 함량 또한 $40 \%$ 회수단백질 대체시 높게 나타났다. 이러한 경향은 $40 \%$ 회수단백질을 대체하여도 제품내 수분 함량의 변화가 없으며, 물리적 특성인 보수력과 가열감량 또한 대조구와 처리구간 에 차이를 나타내지 않아 소시지 제품 내 수분결합력 및 수분손실 률인 loss 값의 차이가 없는 것을 확인하였다. 또한 기능성 물질 첨가에 따른 차이보다는 $40 \%$ 회수단백질 대체는 높은 명도 및 $\mathrm{pH}$ 값을, 경도, 응집성 및 씹힘성을 떨어뜨려 연한 조직감을 형성하였 다.

저장성 실험 결과, 총균수는 대조구에서 오히려 낮게 나타났으며, 지방산패도 값은 $40 \%$ 회수단백질의 대체에 따른 차이보다는 저장 4 주차의 $\mathrm{T} 4, \mathrm{~T} 5$ 및 $\mathrm{T} 6$ 에서 낮게 나타나 동충하초 및 누에고치 $0.1 \%$ 첨가보단 $0.1 \% \mathrm{CLA}$ 및 동충하초, 누에고치 및 CLA 혼합 첨가구에서 지방산패도를 억제시키는 것으로 나타났다. $40 \%$ 회수 단백질 및 기능성 물질 또한 $\mathrm{VBN}$ 값에 영향하였다. 이러한 결과 들은 관능평가 결과, 기존의 축육 소시지와 비교하여 $40 \%$ 회수단 백질 및 기능성 물질을 첨가한 제품과의 기호도 차이를 보이지 않 아 노폐계육의 산업적 활용도뿐만 아니라 동충하초, 누에고치 및 CLA첨가를 통한 기능성 제품 생산이 가능할 것으로 판단된다.

\section{사 사}

이 논문은 농림기술개발사업 지원에 의하여 연구된 것으로 이에 감사 드립니다.

\section{인 용 문 헌}

AOAC 1990. Official methods of analysis (15th ed). Association of Official Analytical Chemists. Washington, DC.

Boles, J. A. and Swan, J. E. 1996. Effect of post-slaughter processing and freezing on the functionality of hot-boned meat from young bull. Meat Sci. 44:11-18.

Buege, J. A. and Aust, J. D. 1978. Microsomal lipid peroxidation. Methods in Enzymol. 52:302-309.

Eggert, J. M., Belury, M. A., Kempa-Steczko, A., Mills, S. E. and Schinckel, A. 2001. Effects of conjugated linoleic acid on the belly firmness and fatty acid composition of genetically lean pigs. J. Anim. Sci. 79:2866-2872.

Huang, H., Wang, H. and Luo, R. C. 2007. Inhibitory effects of cordycps extract on grow of colon cancer cells. J. Chin. Med. Mater. 30:310-313.

Jin, S. K., Kim, I. S., Yang, M. R., Hur, I. C., Jung, H. J., Yang, H. S. and Choi, Y. J. 2008a. Effects of a mixed proportion of Alaska pollack, chicken breast surimi and starch on textural properties of sausage. Kor. J. Anim. Sci. Technol. 50:1-10.

Jin, S. K., Kim, I. S., Choi, Y. J., Yang, H. S. and Park, G. B. 2007a. Effect of cryoprotectants on the quality characteristics of chicken breast surimi manufactured by $\mathrm{pH}$ adjustment during freezing storage. Kor. J. Food Sci. Anim. Res. 27:320-328.

Jin, S. K., Kim, I. S., Jung, H. J., Kim, D. H., Choi, Y. J. and Hur, S. J. 2007b. The development of sausage including meat from spent laying hen surimi. Poultry Sci. 86:2676-2684.

Jin, S. K., Kim, I. S., Nam, Y. W., Park, S. C., Yang, H. S. and Choi, Y. J. 2008b. Textural and sensory properties of crab-taste fish sausage by a different mixed proportion of surimi ingredients. Kor. J. Food Sci. Anim. Res. 28:395-400.

Jung, C. H., Kim, J. S., Jin, S. K., Kim, I. S., Jung, K. J. and Choi, Y. J. 2004. Gelation properties and industrial application of functional protein from fish muscle-2. Properties of functional protein gel from fish, chicken breast and pork leg and optimum formulation. J. Kor. Soc. Food Sci. Nutr. 33:1676-1684.

Knight, M. K. 1992. Red meat and poultry surimi. In: The Chemistry of Muscle Based Food. Johnston, D. E., Knight, M. K. and Ledward, D. A. (eds). The Royal Society of Chemistry, UK, p. 222.

Kristinsson, H. G. and Hultin, H. O. 2003. Role of $\mathrm{pH}$ and ionic strength on water relationships in washed minced chicken breast muscle gels. J. Food Sci. 68:917-922.

Lee, J. I., Ha, Y. J., Jung, J. D., Kang, K. H., Hur, S. J., Park, G. B., Lee, J. D. and Do, C. H. 2004. Changes of quality characteristics of manufactured press ham using conjugated linoleic acid(CLA) accumulated pork during storage periods. Kor. J. Anim. Sci. Technol. 46:646-658.

Meilgaard, M., Civille, G. V. and Carr, B. T. 1999. Sensory evaluation techniques (3rd ed). Boca Ration, Fla: CRC Press Inc. p. 387.

Nam, J. K. and Oh, Y. S. 1995. A study of pharmachological effect of silk fibroin. RDA, Kor. J. Agric. Sci. 37:145-157.

Oehiai, Y., Ochiai, L., Hashimoto, K. and Watabe, S. 2001. Quantitative estimation of dark muscle content in the mackerel meat paste and its productions using antisera against myosin light chains. J. Food Sci. 66:1301-1305.

Park, J. D., Jung, C. H., Kim, J. S., Cho, D. M., Cho, M. S. and Choi, Y. J. 2003. Surimi processing using acid alkali solubilization of fish muscle protein. J. Kor. Soc. Food Sci. Nutr. 32:400-405.

Park, J. W. and Morrissey, M. T. 2000. Manufacturing of surimi from light muscle fish. In: Surimi and Surimi Seafood. Park, J. W. (ed.). New York, Marcel Dekker, p. 23-58.

Rao, Y. K., Fang, S. H. and Tzeng, Y. M. 2007. Evaluation of the 
anti-inflammatory and anti-proliferation tumoral cells activites of Antrodia camphorata, Cordyceps sinensis, and Cinnmomum osmophloeum bark extracts. J. Ethnophrmacol. 114:78-85.

Richards, M. P., Kelleher, S. D. and Hultin, H. O. 1998. Effect of washing with or without antioxidants on quality retention of mackerel fillets during refrigerated and frozen storage. J. Agric. Food Chem. 46:4363-4371.

Sadaki, O. 1996. The development of functional foods and materials. Biochem. 13:44-50.

SAS Institute. 1999. SAS/STAT Software for PC. SAS Institute Inc., Cary, NC, USA.

Sugiyama, K., Kushima, Y. and Muramatsu, K. 1985. Effect of sulfur containing amino acid and glycine on plasma cholesterol level in rats fed on a high cholesterol diet. Agric. Biol. Chem. 49:34553461.

Terpstra, A. H. 2004. Effect of conjugated linoleic acid on body composition and plasma lipids in humans: an overview of the literature. Am. J. Clin. Nutr. 79:352-360.

Totosaus, A. 2004. Functionality of glycosilated heart surimi and heatprecipitated whey proteins in meat batters. J. Muscle Foods. $15: 256-268$

Wang, Y. W. and Jones, P. J. H. 2004. Dietary conjugated linoleic acid and body composition. Am. J. Clin. Nutr. 79:1153-1158.

Witte, V. C., Krause, G. F. and Baile, M. E. 1970. A new extraction method for determining 2-thiobarbituric acid values of pork and beef during storage. J. Food Sci. 35:352-358.

Yang, H. S., Choi, S. G., Jeon, J. T., Park, G. B. and Joo, S. T. 2007. Textural and sensory properties of low fat sausages with added hydrated oatmeal and tofu as texture-modifying agents. Meat Sci. 75:283-289.

高坂和久. 1975. 肉製品。鮮度保持と測定. 食品工業 18:105-111.

(접수일자 : 2009. 9. 21 / 수정일자: 2010. 1. 19 / 채택일자 : 2010. 1. 20) 